This document is the accepted manuscript version of the following article:

Haroni, N. N., Zarafshar, M., Badehian, Z., Sharma, A., \& Bader, M. K. F. (2020).

Tree seedlings suffer oxidative stress but stimulate soil enzyme activity in oil

sludge-contaminated soil in a species-specific manner. Trees: Structure and

Function. https://doi.org/10.1007/s00468-020-01996-7

\title{
Tree Seedlings Suffer Oxidative Stress but Stimulate Soil Enzyme Activity in Oil Sludge- Contaminated Soil in A Species-Specific Manner
}

Naser Norouzi Haroni ${ }^{1}$, Mehrdad Zarafshar ${ }^{* 2}$, Ziaedin Badehian ${ }^{* 3}$, Anket Sharma ${ }^{4}$, Martin Karl-Friedrich Bader ${ }^{5,6}$

1 Ph.D. Student of Forest Science and Ecology, Faculty of Agriculture and Natural Resources, Lorestan University, I. R. Iran.

2 Natural Resources Department, Fars Agricultural and Natural Resources Research and Education Center, AREEO, Shiraz, I.R. Iran.

3 Assistant Prof. Department of Forestry, Faculty of Agriculture and Natural Resources, Lorestan University, I. R. Iran.

4 State Key Laboratory of Subtropical Silviculture, Zhejiang A\&F University, Hangzhou, China

5 Institute for Applied Ecology, School of Science, Auckland University of Technology, 34 St. Paul Street, Auckland 1010, New Zealand.

6 Current address: Swiss Federal Institute of Forest, Snow and Landscape Research (WSL), Zürcherstrasse 111, Birmensdorf 8903, Switzerland

*Corresponding authors: e-mail address; M.zarafshar@areeo.ac.ir and badehian.z@lu.ac.ir, Telephone numbers; 0098- 9126055424 and 0098- 9177303977

\begin{abstract}
The impact of plants on soil enzymatic activity and their potential for remediation of oil-contaminated soil has been widely studied but information about tree species is scarce. Here, we used seedlings of four tree species (Ailanthus altissima Mill, Fraxinus rotundifolia Mill, Melia azedarach L. and Robinia pseudoacacia L.) to investigate rhizosphere effects on key soil enzymes (dehydrogenase, urease, alkaline and acid phosphatase) and to evaluate oxidative stress in response to oil sludge-contaminated soil $\left(0,100,200,400 \mathrm{~g} \mathrm{~kg}^{-1}\right)$.

We observed a large species-specific stimulation of soil enzyme activity often far exceeding the figures in unplanted soil with peaks mostly occurring under low oil contamination $\left(100 \mathrm{~g} \mathrm{~kg}^{-1}\right)$. The strongest stimulatory effect on dehydrogenase and urease activity produced by $R$. pseudoacacia at the low and intermediate and $F$. rotundifolia at the highest contamination level. No clear pattern emerged for acid phosphatase activity, which was equally stimulated by all species at the highest contamination level. Alkaline phosphatase stimulation was dominated by F. rotundifolia at the low and by R. pseudoacacia at the higher oil contamination levels. Foliar $\mathrm{H}_{2} \mathrm{O}_{2}$ rose significantly in a species-specific manner in response to oil contamination, triggering an upregulation of the antioxidant defense, which began to show signs of exhaustion at the highest pollution level and revealed that oxidative stress was highest in A. altissima. Our results imply that phytoremediation efforts can be optimized through carefully designed plant species assemblages aligning stimulatory effects on soil enzyme activity and oxidative stress tolerance with the severity of the oil pollution.
\end{abstract}

Keywords: Antioxidant enzymes, oil sludge, oil-soil contamination, phytoremediation, soil enzymes 


\section{Introduction}

Soil contamination by petroleum sources is one of the big challenges for ecosystem and human health. Exploitation, drilling, and accidental leakage of oil during transportation are common causes for soil pollution (Brakorenko \& Korotchenko 2016, Sajna et al. 2015, Varjani \& Upasani 2017). Oil contamination has immensely negative impacts on the physicochemical and biological properties of soil (Kriksunov 2011, Osse et al. 2018). Petroleum compounds contribute to the contamination of groundwater and adversely affect microbial population density and soil organic matter, which ultimately causes reductions in crop yield (Xie et al. 2018).

Oil sludge is a complex mixture of compounds of NSO (nitrogen-sulfur-oxygen), aromatic hydrocarbons, alkanes, and asphaltenes (Beškoski et al. 2011). The presence of oil sludge in the soil affects various edaphic characteristics, including soil biological properties and may degrade the soil microbiome. Soil enzymes are mainly secreted by microorganisms and plants and play a vital role in soil metabolism ( $\mathrm{Li}$ et al., 2018). As a consequence, their inhibition by heavy metal-contamination has received considerable attention and has been well documented over the last few decades (Namli et al., 2010) but there is much less information available with regard to phytoremediation of contaminated sites by oil sludge.

Soil enzymes play a fundamental role in organic matter turnover and mineral nutrient supply for plant growth, decontamination of materials resistant to biodegradation, $\mathrm{N}_{2}$-fixation, nitrification and denitrification (Das \&Varma 2010). The activity of soil enzymes is widely used as an indicator for soil quality and health because soil enzymatic processes respond very sensitively to changes in the environment and are closely linked to the function and structure of the soil microbial community (Nanekar et al. 2015, Zarafshar et al. 2020) Therefore, investigating the link between environmental pollution and the activity of soil enzymes is crucial for understanding their effect on soil quality and fertility (Varjani \&Upasani 2017). These enzymes may comprise amylase, arylsulfatase, betaglucosidase, cellulase dehydrogenase, phosphatase, protease and released urease from plants, animals, organic compounds and soil microorganisms (Nannipieri et al. 1990). When talking about soil enzyme activity, we need to distinguish between intracellular activity associated with living cells of microorganisms, plants and wildlife, and extracellular activity, without direct linking to living cells (Burns 1982). Urease is an extracellular enzyme produced by microorganisms and involved in the decomposition of urea into ammonium carbonate, which makes it a key enzyme in the nitrogen cycle. The activity of urease has been shown to be more sensitive to pollutants compared to other enzymes (Banks et al. 2003). Phosphatase enzymes play a crucial part in the phosphorus cycle and organic phosphorus decomposition in various terrestrial and (semi-)aquatic ecosystems including lake and flood lands (Wyszkowska \& Wyszkowski 2010, Lemanowicz, 2018). Alkaline phosphatase (intracellular) and acid phosphatase (extracellular) are the major enzymes responsible for the mineralization of organic phosphorus. Activities of both acid and alkaline phosphatase enzymes are influenced by different soil properties, soil organisms, vegetation cover and existence of inhibitor and 
activator substances (Martinez-Salgado et al. 2010). Dehydrogenase enzyme activity is an indicator of the oxidation and health status in biological systems and a marker of microbial activity and the intensity of microbial metabolism in the soil since it only occurs in living microorganisms (Nannipieri et al. 1990). Dindar et al. (2015) argued that soil enzymes are excellent soil health indicators, because: (i) they are closely connected with organic matter, physical traits, microbial activity and biomass in the soil; (ii) they give fundamental information on soil quality since soil enzymes such as urease and phosphatase catalyze numerous reactions in nutrient cycling processes; and (iii) they are quantifiable. In total, more than 100 enzymes operate in soil ecosystems (Dick and Kandeler, 2005) and many of them may provide reliable information about soil quality (Zarafshar et al., 2020).

The close association of soil-borne microorgansims with plants in the rhizosphere provides a powerful system for detoxification and decomposition of soil pollutants such as heavy metals and oil-derived hydrocarbons. Recent studies have shown that the interactions of plants and microorganisms play a critical role in detoxifying soil and removing PAHs from soils (Khan et al. 2013; Oliveira et al. 2014). The positive effect of plants on the enzymatic activity in oil-contaminated soil has been shown previously (Jeelani et al. 2018, Roy et al. 2014, Xun et al. 2015). For instance, Wang et al. (2008) studied the effects of three grass species on enzyme activity in a soil contaminated by petroleum compounds and found that the presence of plants stimulated dehydrogenase activity compared to unplanted soil. Wyszkowska et al. (2010) demonstrated that soil enzyme activity decreased with increasing levels of soil contamination in the presence of herbaceous phytoremediator plants like Brassica napus and Avena sativa. However, they also found species-specific differences in enzyme stimulation, urease, dehydrogenase and alkaline phosphatase activities were higher in B. napus planted soil, while Avena sativa planted soils displayed a higher rate of alkaline phosphatase activity.

A range of plant species shows potential for phytoremediation of petroleum compounds in soils, but at the same time the exposure to oil can lead to severe oxidative stress and the deterioration of plant health (Panchenko et al. 2017). An increase in reactive oxygen species (ROS), such as hydrogen peroxide, is a clear sign of oxidative stress in plants (Mithöfer et al. 2004) and screening phytoremediation candidates for oxidative stress markers can provide valuable information about their abiotic stress tolerance or resistance and their suitability for remediation projects. At the same time, investigating antioxidant enzyme activity in plants exposed to oil-contaminated soils may help understand their defence mechanisms against oil-induced increases in oxidative stress (Panchenko et al. 2017).

Information on the use of soil enzymes as bioindicators for petroleum hydrocarbon contamination is scarce, which prompted us to investigate the relationship between soil enzyme activity and the level of oil sludge contamination for soil health restoration. To quantify the rhizosphere effect and to determine whether species-specific soil enzyme stimulation occurs, we compared the activities of four key enzymes (dehydrogenase, urease, acid and alkaline phosphatase) in unplanted soil to soil planted with seedlings of four forest tree species: Ailanthus altissima Mill., Fraxinus rotundifolia Mill., Melia 
azedarach L. and Robinia pseudoacacia L. We also examined oil sludge-related oxidative stress and the response of the antioxidant defense system in the tree seedlings. We hypothesized a tree speciesspecific stimulation of soil enzymatic activity and expected $R$. pseudoacacia to have the greatest impact due to its symbiotic $\mathrm{N}_{2}$-fixation and therefore increased availability of $\mathrm{N}$ in the soil. Furthermore, we anticipated an increase in oxidative stress (using hydrogen peroxide as a proxy) in response to increasing oil contamination with subsequent upregulation of the antioxidant system.

\section{Materials and methods}

\subsection{Study objects and soil samples}

For this experiment, seeds of A. altissima, F. rotundifolia, M. azedarach and R. pseudoacacia were soaked in water for 48 hours. The oil sludge was provided from the Isfahan Oil Refining Company and the uncontaminated soil was taken from a farm land in Lorestan Province, College of Agriculture and Natural Resources ( $\left.33^{\circ} 26^{\prime} 14.4^{\prime \prime} \mathrm{N}, 48^{\circ} 15^{\prime} 38.7^{\prime \prime} \mathrm{E}\right)$, in the south west Khorramabad city. The soil was collected from the upper soil profile (0-30 cm, A horizon).

\subsection{Soil and oil sludge characteristics}

Single, mixed composite samples, consisting of three randomly collected subsamples, were formed from soil or oil sludge material and transferred to the soil laboratory for physical and chemical analyses. The samples were air-dried and passed through a $2 \mathrm{~mm}$ mesh. Soil texture and bulk density (BD) and actual density were determined using the hydrometer (Bouyoucos 1962) and clod method (Grossman \&Reinsch 2002), respectively. Then, the $\mathrm{pH}$ value and electrical conductivity (EC) were recorded using $\mathrm{pH}$ meter and EC meter, respectively (Burt 2004). Finally, the concentration of some heavy metals and elements in the soil and oil sludge were determined by Inductively Coupled Plasma Emission Spectroscopy (ICP-ES-710 Varian, Australia) (Tables 1 and 2).

Table 1 General physical and chemical traits of the soil used in the pots.

\begin{tabular}{cccccccc}
\hline pH & $\begin{array}{c}\text { EC } \\
(\mathbf{d s} / \mathbf{m})\end{array}$ & $\begin{array}{c}\text { Clay } \\
(\%)\end{array}$ & $\begin{array}{c}\text { Silt } \\
(\%)\end{array}$ & $\begin{array}{c}\text { Sand } \\
(\%)\end{array}$ & Texture & Bulk weight $\left(\mathbf{g} / \mathbf{c m}^{\mathbf{3}}\right)$ & Actual density $\left(\mathbf{g} / \mathbf{c m}^{\mathbf{3}}\right)$ \\
\hline 7.4 & 0.6 & 41 & 30 & 29 & Clay loamy & 1.3 & 2.63 \\
\hline
\end{tabular}


Table 2 Chemical characteristics of soil and oil sludge used in the experiment on seedlings exposed to oil sludge contamination

\begin{tabular}{ccccccccc}
\hline chemical characteristics & $\begin{array}{c}\mathbf{A g} \\
(\mathbf{g} / \mathbf{k g})\end{array}$ & $\begin{array}{c}\mathbf{A l} \\
(\mathbf{g} / \mathbf{k g})\end{array}$ & $\begin{array}{c}\mathbf{B e} \\
(\mathbf{m g} / \mathbf{k g})\end{array}$ & $\begin{array}{c}\mathbf{C a} \\
(\mathbf{g} / \mathbf{k g})\end{array}$ & $\begin{array}{c}\mathbf{C d} \\
(\mathbf{g} / \mathbf{k g})\end{array}$ & $\begin{array}{c}\mathbf{C u} \\
(\mathbf{g} / \mathbf{k g})\end{array}$ & $\begin{array}{c}\mathbf{F e} \\
(\mathbf{g} / \mathbf{k g})\end{array}$ & $\begin{array}{c}\mathbf{K} \\
(\mathbf{g} / \mathbf{k g})\end{array}$ \\
\hline $\begin{array}{c}\text { Soil } \\
\text { Oil sludge }\end{array}$ & 0.00029 & 45.722 & 0.0011 & $>10 \%$ & 0.00034 & 0.033 & 28.709 & 10.744 \\
& 0.0006 & 12.615 & $<0.0001$ & 36.473 & 0.0011 & 0.73 & 33.972 & 2.190 \\
\hline chemical characteristics & $\mathbf{M g}$ & $\mathbf{M o}$ & $\mathbf{N i}$ & $\mathbf{P b}$ & $\mathbf{P}$ & $\mathbf{S r}$ & $\mathbf{V}$ & $\mathbf{Z n}$ \\
& $\mathbf{( g / k g )}$ & $\mathbf{( g / \mathbf { k g } )}$ & $\mathbf{( g / \mathbf { k g } )}$ & $\mathbf{( g / \mathbf { k g } )}$ & $\mathbf{( g / \mathbf { k g } )}$ & $\mathbf{( g / \mathbf { k g } )}$ & $\mathbf{( g / \mathbf { k g } )}$ & $\mathbf{( g / \mathbf { k g } )}$ \\
\hline Soil & 16.287 & 0.00067 & 0.103 & 0.042 & 0.544 & 0.196 & 0.078 & 0.501 \\
Oil sludge & 4.527 & 0.0157 & 0.152 & 0.093 & 10.933 & 0.495 & 0.227 & 1.332 \\
\hline
\end{tabular}

\subsection{Experimental design}

The experiment was carried out in a greenhouse under controlled conditions. The average temperature during the experiment was $25 \pm 10{ }^{\circ} \mathrm{C}$ with an average relative humidity of $44 \%$ (85\% maximum, 21 $\%$ minimum). The greenhouse is located in Khorramabad city, Iran ( $\left.33^{\circ} 26^{\prime} 22.4^{\prime \prime} \mathrm{N}, 48^{\circ} 15^{\prime} 44.3^{\prime \prime} \mathrm{W}\right)$ at $1148 \mathrm{~m}$ a.s.l. The climate is moderate and semi-humid Mediterranean. The mean annual precipitation and temperature are $512.9 \mathrm{~mm}$ and $17.6{ }^{\circ} \mathrm{C}$ respectively (IRIMO 2014). The study lasted for 240 days from 13 February to 11 October 2017.

The study was laid out as a factorial experiment following a fully randomized design with two fixed factors: species (four tree species including A. altissima, F. rotundifolia, M. azedarach and $R$. pseudoacacia) and oil sludge concentration (four levels: 0, 100, 200 and $400 \mathrm{~g} \mathrm{~kg}^{-1}$ ). The range of oil sludge addition was guided by the results of a pre-treatment study showing extremely poor germination at contamination levels exceeding $400 \mathrm{~g} \mathrm{~kg}^{-1}$. Seeds of the four tree species were planted in artificially oil sludge-contaminated soils. Seed-free oil sludge-contaminated soils served as controls. Before sowing the seeds, the dried oil sludge was manually mixed with the soil to form a homogenous combination. Contaminated soils were kept in the shade at ambient temperature for 5 days before they were allocated to experimental units (pots) with $5 \mathrm{~kg}$ capacity and dimensions of $20 \times 25 \mathrm{~cm}$. Next, fifteen seeds of the same species were sown in three pots (five seeds in each pot as subreplicates). The pots were transferred to the greenhouse and irrigated to field capacity every 2 days. At the end of the germination period, seedling emergence and survival under the various oil pollution levels were assessed (Table 3) and the number of seedlings in each pot was reduced to one healthy seedling. Those remaining seedlings were irrigated as described above until the end of the experiment.

After 240 days, 4-5 leaf samples were collected from the upper crown of the seedlings to determine antioxidative enzyme activities and $\mathrm{H}_{2} \mathrm{O}_{2}$ content. At the end of the study, soil samples were taken from all pots (three pots for each oil treatment by tree species combination) and immediately stored in a refrigerator at $4 \stackrel{\circ}{\mathrm{C}}$ for the soil enzyme assay. 


\subsection{Soil enzyme assays}

\section{Dehydrogenase activity}

Soil dehydrogenase activity was determined by the reduction of triphenyltetrazolium chloride to triphenyl formazan (TPF) and reported as $\mu \mathrm{g}$ of TPF released per gram soil per hour (Casida Jr et al. 1964).

\section{Urease activity}

The assay for urease activity was based on the determination of $\mathrm{NH}_{4}{ }^{+}$released by urease when the soil was incubated with the THAM (Tris (hydroxymethyl) aminomethane) buffer ( $\mathrm{pH}=9$ ), a $0.02 \mathrm{M}$ urea solution and toluene at $37^{\circ} \mathrm{C}$ for $2 \mathrm{~h}$ (Tabatabai et al. 1972).

\section{Soil phosphatase activity}

Alkaline and acid phosphatase were determined by using samples of $0.5 \mathrm{~g}$ of dry soil according to the method of (Tabatabai et al. 1969). Each soil sample was mixed with $400 \mu \mathrm{L}$ of modified universal sterile buffer (at pH 5.8 for acid phosphatase and $\mathrm{pH} 11$ for alkaline phosphatase) and $100 \mu \mathrm{L}$ of pnitrophenyl phosphate solution (PNPP) prior to incubation for $1 \mathrm{~h}$ at $37{ }^{\circ} \mathrm{C}$ on a rotary shaker. The reaction was stopped by adding $100 \mu \mathrm{L}$ of $\mathrm{CaCl}_{2}$ and $400 \mu \mathrm{L}$ of $\mathrm{NaOH}$, and the soil suspensions were centrifuged at 12,000 rpm for $10 \mathrm{~min}$. Then, absorbance readings were taken at $400 \mathrm{~nm}$ using a UVVIS spectrophotometer (PhotonixAr 2015, Teifsanje Co. Ltd., Tehran, Iran).

\subsection{Plant biochemical parameters}

\section{Hydrogen peroxide $\left(\mathrm{H}_{2} \mathrm{O}_{2}\right)$}

Foliar hydrogen peroxide $\left(\mathrm{H}_{2} \mathrm{O}_{2}\right)$ content in seedlings, was determined by extracting leaf samples $(0.5$ g) with $5 \mathrm{ml}$ trichloroacetic acid (TCA) $(0.1 \%$, w/v) ice bath homogenate, followed by $12,000 \times \mathrm{g}$ centrifugation for $15 \mathrm{~min}$ (Velikova et al. 2000).

\section{Peroxidase (POD)}

POD extraction buffer contained $50 \mu \mathrm{M}$ phosphate ( $\mathrm{pH}$ 7.8), $25 \mu \mathrm{M}$ guaiacol, $200 \mu \mathrm{M} \mathrm{H}_{2} \mathrm{O}_{2}$, and the change in absorbance of the leaf samples was measured at $470 \mathrm{~nm}$ (Zhang \&Qu 1990).

\section{Ascorbate peroxidase (APX)}

APX activity in leaves was assayed according to Nakano et al. (1981). The reaction mixture $\left(1.5 \mathrm{~cm}^{3}\right)$ contained $50 \mathrm{mM}$ phosphate buffer $(\mathrm{pH}=6.0), 0.1 \mathrm{mM}$ EDTA, $0.5 \mathrm{mM}$ ascorbate, $1.0 \mathrm{mM} \mathrm{H}_{2} \mathrm{O}_{2}$, and $0.05 \mathrm{~cm}^{3}$ enzyme extract. The reaction was started by the addition of $\mathrm{H}_{2} \mathrm{O}_{2}$, and ascorbate oxidation was measured at $290 \mathrm{~nm}$ for $1 \mathrm{~min}$.

\section{Catalase (CAT)}

For measurements of the foliar CAT (EC 1.11.1.6) activity, extraction was done in a buffer containing $50 \mathrm{mM}$ Tris- $\mathrm{HCl}$ (pH 7.0), $0.1 \mathrm{mM}$ EDTA, $1 \mathrm{mM}$ phenylmethanesulfonyl fluoride (PMSF) and $0.3 \mathrm{~g}$ $\mathrm{g}^{-1}$ fw PVP. The enzyme extract was prepared as mentioned above. Activity was measured by the method of Aebi (1974). The $3 \mathrm{~mL}$ reaction mixture comprised $50 \mathrm{mM}$ sodium phosphate buffer (pH 
7.0), $20 \mathrm{mM} \mathrm{H}_{2} \mathrm{O}_{2}$ and enzyme extract. Decrease in the absorbance due to consumption of $\mathrm{H}_{2} \mathrm{O}_{2} \mathrm{was}$ measured at $240 \mathrm{~nm}$ (extinction coefficient $39.4 \mathrm{mM}^{-1} \mathrm{~cm}^{-1}$ ).

\subsection{Statistical analysis}

All data were analyzed using the SPSS statistical package version 16 (SPSS Inc., Chicago, IL, USA). A series of two-way analysis of variance (two-way ANOVA) models were used to test the main and interaction effects of tree species and oil-contamination on soil enzyme activity and four plant biochemical variables. Significant terms were followed up with a post-hoc analysis using Tukey's Honest Significant Difference (HSD) test.

The assumptions of normality and homogeneity of variance were checked on the raw data using the Kolmogorov-Smirnov test and Levene's test, respectively. After model fitting, we also inspected the residual plots (normalized residuals vs. fitted values and quantile-quantile plots) to evaluate the assumptions of the models graphically. No gross violations from normality or variance homogeneity were detected. All experiments were performed using three replicates.

\section{Results}

\subsection{Impact of oil sludge contamination on soil enzyme activities of the tree species}

The main effects of 'oil sludge contamination' and 'species' as well as their interaction were statistically significant for all studied soil enzyme activities (Table 3 ). The oil sludge $\times$ species interaction indicated that the effect of oil sludge contamination on soil enzymatic activity varied significantly with tree species which was further investigated with a post-hoc analysis (Fig. 1).

Table 3. Results of a series of two-way ANOVAs used to determine the effects of oil sludge contamination, tree species identity and their interaction on the activity of four soil enzyme. $d f_{\text {num }}=$ numerator degrees of freedom, $d f_{\text {den }}=$ denominator degrees of freedom

\begin{tabular}{cccccc}
\hline Effect & Soil enzymes & $\boldsymbol{d} \boldsymbol{f}_{\text {num }}$ & $\boldsymbol{d} \boldsymbol{f}_{\text {den }}$ & $\boldsymbol{F}$ & $\boldsymbol{P}$ \\
\hline \multirow{3}{*}{ Oil Sludge } & Dehydrogenase & 3 & 40 & 143.167 & $<0.001^{* * *}$ \\
& Urease & 3 & 40 & 182.911 & $<0.001^{* * *}$ \\
& Acid phosphatase & 3 & 40 & 68.566 & $<0.001^{* * *}$ \\
& Alkaline phosphatase & 3 & 40 & 71.885 & $<0.001^{* * *}$ \\
\hline \multirow{3}{*}{ Species } & Dehydrogenase & 4 & 40 & 89.682 & $<0.001^{* * *}$ \\
& Urease & 4 & 40 & 225.402 & $<0.001^{* * *}$ \\
& Acid phosphatase & 4 & 40 & 54.461 & $<0.001^{* * *}$ \\
& Alkaline phosphatase & 4 & 40 & 108.153 & $<0.001^{* * *}$ \\
\hline \multirow{3}{*}{ Oil Sludge $\times$ Species } & Dehydrogenase & 12 & 40 & 33.948 & $<0.001^{* * *}$ \\
& Urease & 12 & 40 & 46.489 & $<0.001^{* * *}$ \\
& Acid phosphatase & 12 & 40 & 6.122 & $<0.001^{* * *}$ \\
& Alkaline phosphatase & 12 & 40 & 24.462 & $<0.001^{* * *}$ \\
\hline
\end{tabular}

In the uncontaminated control treatment, no statistically significant differences in dehydrogenase activity occurred, apart from soil planted with $A$. altissima seedlings, which showed significantly higher activity than the unplanted soil $(+44 \%$, Fig. 1 a). When oil sludge contamination was present, the activity of dehydrogenase in planted soil was always significantly higher than that of bare soil, except for $A$. altissima pots at $200 \mathrm{~g} \mathrm{~kg}^{-1}$ contamination, which showed no significant difference in the activity of soil dehydrogenase compared to bare contaminated soil. However, even in the unplanted soil, dehydrogenase activity increased significantly by more than $50 \%$ in response to low and medium 
oil sludge contamination but dropped to the overall lowest activity when $400 \mathrm{~g} \mathrm{~kg}^{-1}$ oil sludge were added (not significantly different from the uncontaminated control). The overall peak activity of dehydrogenase was observed in soil planted with $R$. pseudoacacia in the $100 \mathrm{~g} \mathrm{~kg}^{-1}$ oil sludge treatment where it was significantly higher than all the other activities, exceeding the dehydrogenase activity in the unplanted control soil by a factor of 2.6 (Fig. 1 a). A similar but less pronounced pattern was seen at the $200 \mathrm{~g} \mathrm{~kg}^{-1}$ oil contamination level, where dehydrogenase activity in R. pseudoacacia-planted soil was $44-94 \%$ higher compared to soil planted with the remaining tree species and about twice as high as the activity measured in unplanted control soil. At the $400 \mathrm{~g} \mathrm{~kg}^{-1}$ contamination treatment, all tree species stimulated dehydrogenase activity more strongly compared to the lower contamination levels, with the exception of pots planted with $R$. pseudoacacia, which showed significantly lower activity relative to the 100 and $200 \mathrm{~g} \mathrm{~kg}^{-1}$ oil sludge treatments. At the highest oil contamination level, all dehydrogenase activities differed significantly: soil planted with $F$. rotundifolia showed the highest activity of dehydrogenase ( $+360 \%$ compared to the seedling-free control), while soil planted with $A$. altissima and $M$. azedarach showed somewhat lower activity of dehydrogenase (270 - $290 \%$ higher than the control) and the lowest level of enzymatic stimulation occurred in soil under R. pseudoacacia (Fig. 1 a). The peak magnitude of $R$. pseudoacacia's stimulatory effect on dehydrogenase activity seen at $100 \mathrm{~g} \mathrm{~kg}^{-1}$ oil sludge addition dropped by roughly $30 \%$ with each doubling of the contamination level. The trend for urease activity strongly resembled the dehydrogenase pattern but urease activity in the unplanted pots remained unchanged with increasing oil sludge contamination (Fig. $1 \mathrm{~b}$ ). Irrespective of oil contamination level, seedling presence significantly stimulated urease activity relative to the unplanted control soil by $60-380 \%$ (Fig. 1 b). Overall, the highest activity occurred in soil planted with $R$. pseudoacacia at the $100 \mathrm{~g} \mathrm{~kg}^{-1}$ oil sludge contamination level (Fig. $1 \mathrm{~b}$ ). All tree species produced a significant increase in urease activity at $100 \mathrm{~g} \mathrm{~kg}^{-1}$ compared to the activity levels seen in uncontaminated soil. The magnitude of this stimulatory effect on urease activity decreased significantly from the 100 to the $200 \mathrm{~g} \mathrm{~kg}^{-1}$ oil contamination level in all tree species followed by a significant increase in the most severely contaminated soil, except for $R$. pseudoacacia whose effect showed a further significant decline at the highest contamination treatment $(-46 \%$ compared to the peak urease activity caused at $100 \mathrm{~g} \mathrm{~kg}^{-1}$ ). Both, F. rotundifolia and A. altissima exerted their strongest effect on urease activity at the $400 \mathrm{~g} \mathrm{~kg}^{-1}$ oil contamination treatment which was significantly higher than the increases in activity caused by those species at the lower contamination levels. The highest magnitude of urease stimulation linked to M. azederach also occurred in the $400 \mathrm{~g} \mathrm{~kg}^{-1}$ oil sludge treatment (although not statistically different from the effect observed at $100 \mathrm{~g} \mathrm{~kg}^{-1}$ ) and was very similar to that of $A$. altissima.

The activity of acid phosphatase in unplanted soil increased significantly by $18 \%$ in the 100 and 200 $\mathrm{g} \mathrm{kg}^{-1}$ contamination treatment compared to the uncontaminated control but returned to control levels in the most heavily contaminated soil (Fig. 1c). At each level of contamination, we observed consistently higher activity in soil planted with tree seedlings compared to unplanted soil (Fig. $1 \mathrm{c}$ ). 
However, R. pseudoacacia did not show the same stimulatory effect it had on dehydrogenase and urease activity. The highest activities of acid phosphatase exceeded $1400 \mu \mathrm{g} \rho \mathrm{NP} \mathrm{g}^{-1} \mathrm{dm} \mathrm{h}^{-1}$ and were found in soil planted with A. altissima and R. pseudoacacia in the $200 \mathrm{~g} \mathrm{~kg}^{-1}$ oil sludge treatment and $F$. rotundifolia at the $100 \mathrm{~g} \mathrm{~kg}^{-1}$ level of contamination. At the highest oil contamination level of 400 $\mathrm{g} \mathrm{kg}^{-1}$, acid phosphatase activity was similarly stimulated across tree species but to a significantly lesser extent compared with the remaining contamination levels, apart from F. rotundifolia whose effect did not differ significantly from the one seen at $200 \mathrm{~g} \mathrm{~kg}^{-1}$ (Fig. $1 \mathrm{c}$ ).

The activity of alkaline phosphatase in unplanted control soil did not change significantly with increasing oil contamination level (Fig. $1 \mathrm{~d}$ ). Tree seedling in the uncontaminated soil presence significantly stimulated alkaline phosphatase activity relative to the unplanted control, expect for $A$. altissima which produced activity levels similar to the control. Overall, soil planted with $F$. rotundifolia in the $100 \mathrm{~g} \mathrm{~kg}^{-1}$ oil contamination treatment showed the strongest activity of the enzyme which was about $280 \%$ higher than the control activity. However, the stimulatory effect of $F$. rotundifolia declined significantly with increasing soil contamination. At the $200 \mathrm{~g} \mathrm{~kg}^{-1}$ oil sludge treatment, $F$. rotundifolia-related enzyme activity dropped down to values seen in uncontaminated soil and even lower than that at the strongest contamination and in both instances the other tree species produced significantly larger effects. In the 200 and $400 \mathrm{~g} \mathrm{~kg}^{-1}$ oil contamination treatments, pots containing $R$. pseudoacacia showed peak activities of alkaline phosphatase which were significantly higher than all other enzyme activities in planted soil and translated into a $194 \%$ and $234 \%$ increase over the control in the 200 and $400 \mathrm{~g} \mathrm{~kg}^{-1}$ treatments, respectively. A. altissima and M. azedarach displayed the next larger effects on alkaline phosphatase activity in the 200 and $400 \mathrm{~g} \mathrm{~kg}^{-1}$ contamination treatments without significant differences in magnitude (Fig. $1 \mathrm{~d}$ ).

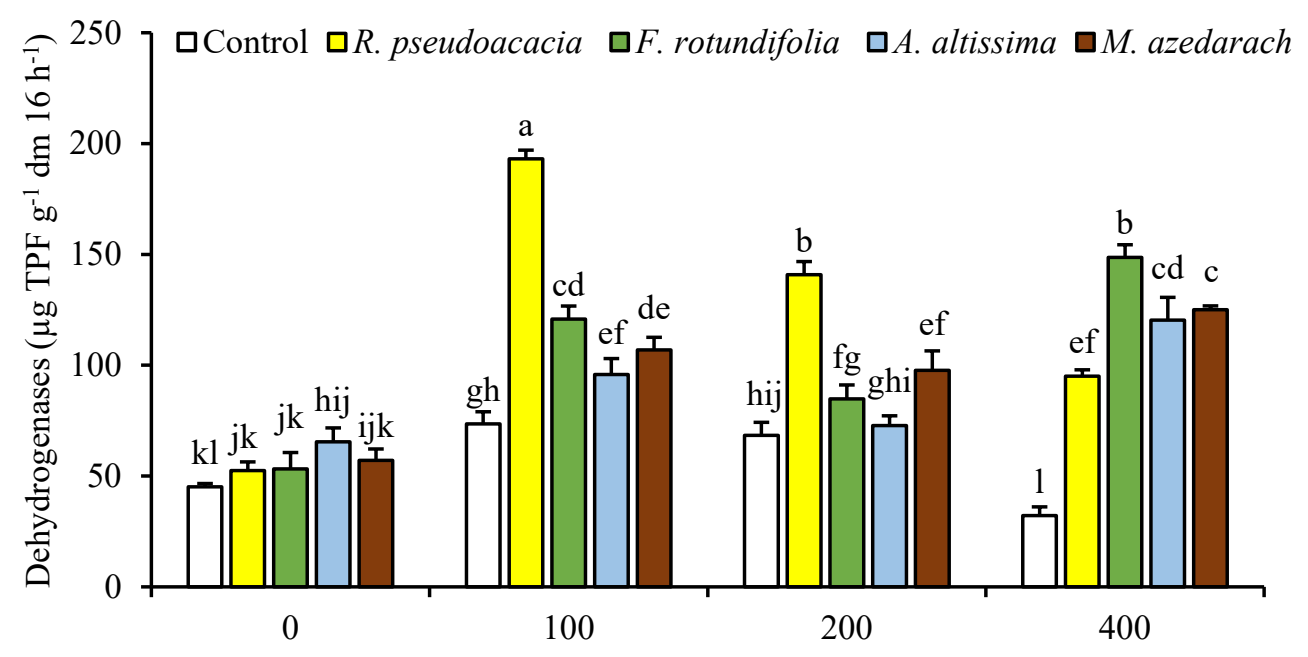



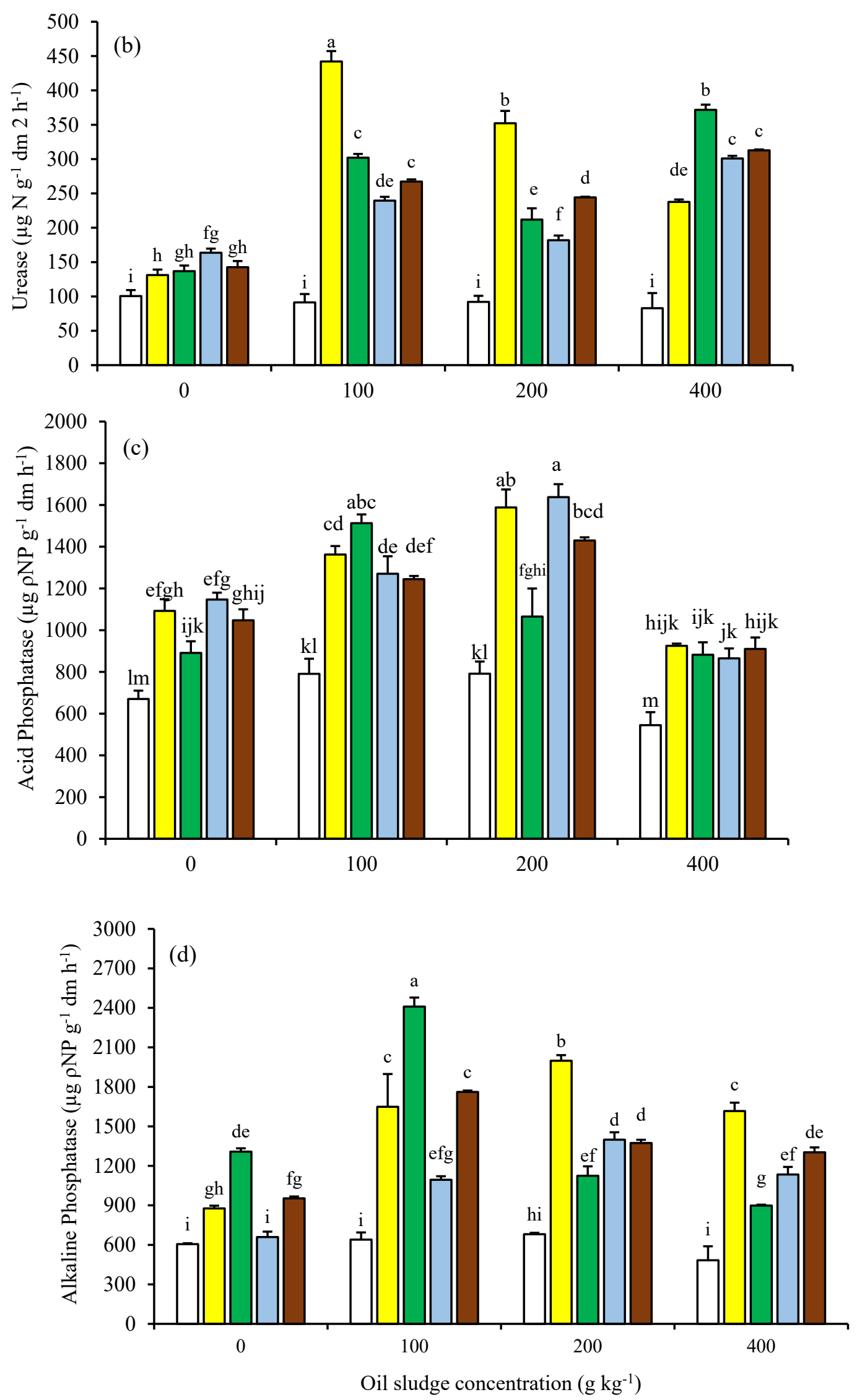

Fig. 1 Activities of four key soil enzymes in unplanted soil (control) and soil planted with one of four species of forest tree seedlings in response to a 240-day oil sludge contamination treatment $(0$, $100,200,400 \mathrm{~g} \mathrm{~kg}^{-1}$ soil). Different lower-case letters indicate statistically significant differences based on Tukey's Honest Significant Difference (HSD) test ( $\alpha=0.05)$. Means \pm SE, $n=3$. 


\subsection{Impact of oil sludge contamination on foliar $\mathrm{H}_{2} \mathrm{O}_{2}$ content and antioxidant enzymes}

For all four leaf biochemical parameters, we detected statistically significant main effects of "oil sludge contamination' and 'species' as well as a significant interaction between these two factors implying that the impact of oil sludge contamination on foliar plant biochemistry was species-dependent (Table

Table 4. Results of a series of two-way ANOVAs used to determine the effects of oil sludge contamination, tree species identity and their interaction on four foliar biochemical parameters of the studied tree species. $d f_{\text {num }}=$ numerator degrees of freedom, $d f_{\text {den }}=$ denominator degrees of freedom

\begin{tabular}{cccccc}
\hline Effect & Plant biochemical parameters & $\boldsymbol{d f}_{\text {num }}$ & $\boldsymbol{d} \boldsymbol{f}_{\text {den }}$ & $\boldsymbol{F}$ & $\boldsymbol{P}$ \\
\hline \multirow{3}{*}{ Oil Sludge } & Hydrogen peroxide & 3 & 32 & 149.409 & $<0.001^{* * *}$ \\
& Peroxidase & 3 & 32 & 98.721 & $<0.001^{* * *}$ \\
& Ascorbate peroxidase & 3 & 32 & 95.981 & $<0.001^{* * *}$ \\
& Catalase & 3 & 32 & 38.308 & $<0.001^{* * *}$ \\
\hline \multirow{2}{*}{ Species } & Hydrogen peroxide & 3 & 32 & 4.488 & $0.010^{*}$ \\
& Peroxidase & 3 & 32 & 20.400 & $<0.001^{* * *}$ \\
& Ascorbate peroxidase & 3 & 32 & 91.938 & $<0.001^{* * *}$ \\
& Catalase & 3 & 32 & 54.509 & $<0.001^{* * *}$ \\
\hline \multirow{2}{*}{ Oil Sludge $\times$ Species } & Hydrogen peroxide & 9 & 32 & 10.586 & $<0.001^{* * *}$ \\
& Peroxidase & 9 & 32 & 4.615 & $<0.001^{* * *}$ \\
& Ascorbate peroxidase & 9 & 32 & 5.038 & $<0.001^{* * *}$ \\
& Catalase & 9 & 32 & 3.313 & $0.006^{* *}$ \\
\hline
\end{tabular}

The foliar $\mathrm{H}_{2} \mathrm{O}_{2}$ concentration was lowest in the uncontaminated control treatment and tended to increase in all species with increasing oil sludge contamination but this rise was not always statistically significant (Fig. 2 a). In uncontaminated soil, $R$. pseudoacacia showed significantly lower foliar $\mathrm{H}_{2} \mathrm{O}_{2}$ content (-14\%) than F. rotundifolia and A. altissima, while the intermediate values of M. azedarach were not significantly different from any of the other species (Fig. 2a). At the $100 \mathrm{~g} \mathrm{~kg}^{-1}$ contamination level, $\mathrm{H}_{2} \mathrm{O}_{2}$ content in $R$. pseudoacacia foliage was significantly lower compared to the remaining species (ca. $-17 \%$ ) and was still similar to the values seen in the uncontaminated control. When 200 $\mathrm{g} \mathrm{kg}^{-1}$ oil sludge were added, $F$. rotundifolia leaves showed the highest $\mathrm{H}_{2} \mathrm{O}_{2}$ content but differences to the other species were only statistically significant for $R$. pseudoacacia and A. altissima. Surprisingly, A. altissima was the only species whose foliar $\mathrm{H}_{2} \mathrm{O}_{2}$ content did not respond to a doubling of the oil sludge concentration from 100 to $200 \mathrm{~g} \mathrm{~kg}^{-1}$. Under the most severe oil contamination (400 $\mathrm{g} \mathrm{kg}^{-1}$ ), all tree species showed significantly higher foliar $\mathrm{H}_{2} \mathrm{O}_{2}$ content compared with seedlings grown in uncontaminated soil and in the $100 \mathrm{~g} \mathrm{~kg}^{-1}$ oil pollution but only $R$. pseudoacacia and A. altissima exhibited significant increases compared to the $200 \mathrm{~g} \mathrm{~kg}^{-1}$ treatment $(+32.5 \%$ and $+12.6 \%$, respectively). Overall, the maximum $\mathrm{H}_{2} \mathrm{O}_{2}$ content was observed in $R$. pseudoacacia seedlings at the highest oil sludge contamination level, which was on average $17 \%$ higher than the $\mathrm{H}_{2} \mathrm{O}_{2}$ content seen in the three remaining species at this contamination level and $76 \%$ higher compared to $R$. pseudoacacia seedlings growing in uncontaminated soil.

All tree species showed their lowest peroxidase (POD) activity under control conditions and a significant rise to maximal values in the $100 \mathrm{~g} \mathrm{~kg}^{-1}$ oil sludge treatment followed by a return to control 
levels with increasing contamination, except for $R$. pseudoacacia whose POD activity remained significantly elevated at the strongest contamination (relative to the control) (Fig. 2 b). Overall, the highest level of POD activity was found in seedlings of A. altissima exposed to $100 \mathrm{~g} \mathrm{~kg}^{-1}$ oil sludge concentration, which translated into a $158 \%$ increase over the level of activity measured in conspecific control seedlings.

Under control conditions, A. altissima and M. azedarach displayed similar but significantly higher ascorbate peroxidase (APX) activity than the two other tree species. A steep increase in APX activity from the uncontaminated control to the $100 \mathrm{~g} \mathrm{~kg}^{-1}$ oil sludge concentration occurred in all species and was followed by a significant decline at the two highest oil sludge additions back to the activity level seen in the control, except for A. altissima (Fig. 1 c). Seedlings of A. altissima showed the highest APX activity of all trees at 100 and $200 \mathrm{~g} \mathrm{~kg}^{-1}$ oil sludge concentration ( $c a .13 \Delta \mathrm{A} \mathrm{min}^{-1} \mu \mathrm{g}^{-1}$ protein) and also displayed a significant activity reduction at the highest contamination treatment. However, despite this decline the APX activity associated with the $400 \mathrm{~g} \mathrm{~kg}^{-1}$ oil contamination was still significantly higher than the activity in leaves of the control seedlings. The maximum foliar APX activity of $F$. rotundifolia occurred at the $100 \mathrm{~g} \mathrm{~kg}^{-1}$ contamination level followed by a significant decline of $29 \%$ in the $200 \mathrm{~g} \mathrm{~kg}^{-1}$ contamination treatment and a further significant drop to values similar to the control under the most severe oil-contamination. F. rotundifolia seedlings growing in the uncontaminated and the most severely oil-contaminated soil had the lowest overall APX activity. The APX activity levels associated with the 100 and $200 \mathrm{~g} \mathrm{~kg}^{-1}$ contamination treatments were similar to those of $R$. pseudoacacia (Fig. $1 \mathrm{c}$ ).

In uncontaminated soil, A. altissima showed significantly higher catalase (CAT) activity than $M$. azedarach and both activities were significantly higher compared to the similar values observed in $R$. pseudoacacia and F. rotundifolia (Fig. 2 d). Similar to APX, the highest activity of the catalase enzyme occurred in seedlings of $A$. altissima under 100 and $200 \mathrm{~g} \mathrm{~kg}^{-1}$ oil sludge concentration. CAT activity in the remaining species also showed a significant increase over the control at 100 or $200 \mathrm{~g}$ $\mathrm{kg}^{-1}$ but returned to control levels at the highest oil contamination treatment, apart from $F$. rotundifolia whose CAT activity also decreased significantly but yet remained significantly higher than the control. Overall, the lowest recordings of CAT activity were observed in leaves of $F$. rotundifolia and $R$. pseudoacacia growing in uncontaminated soil and in case of the latter species, also in the most severely oil-contaminated soil (Fig.1 d). 

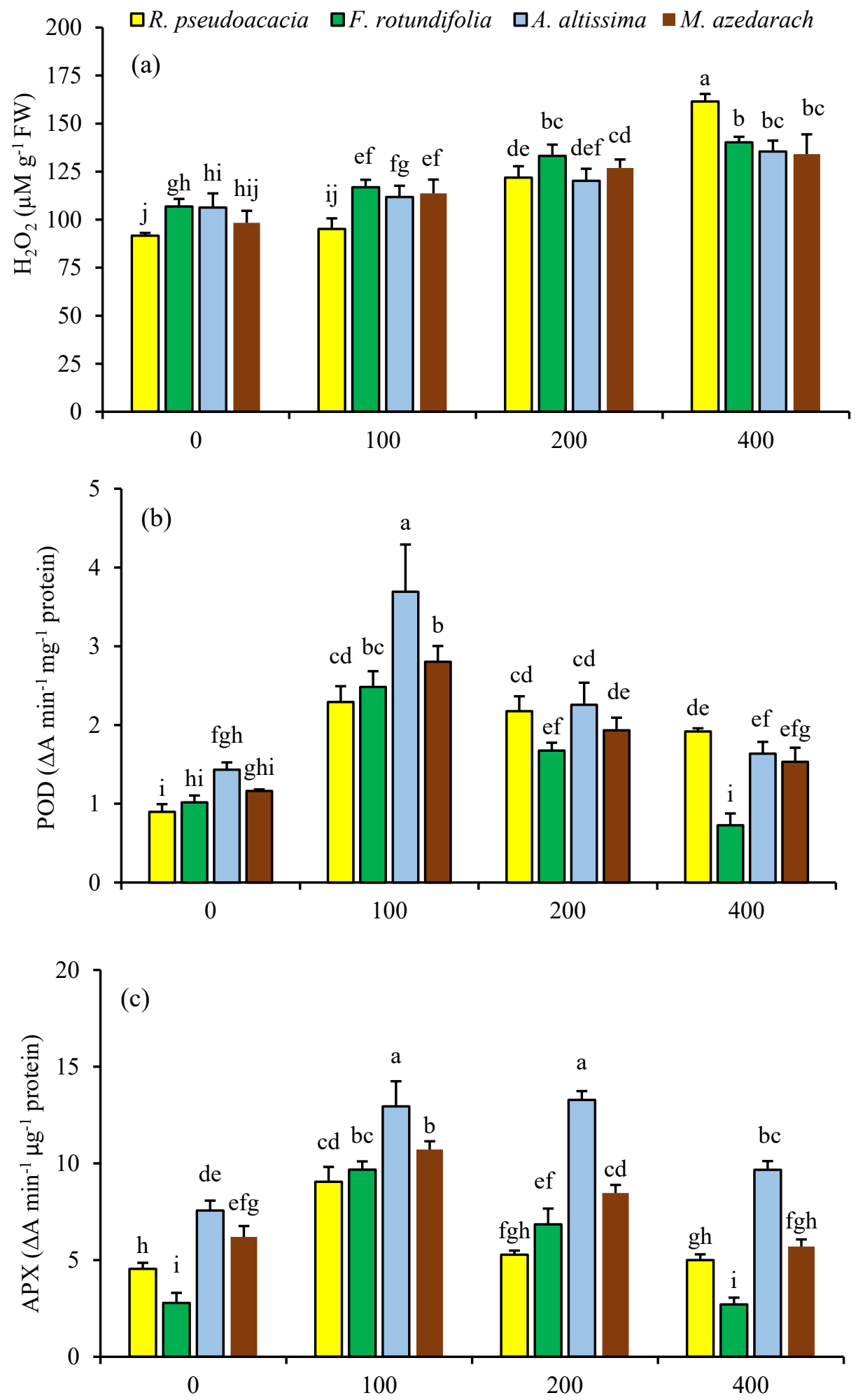


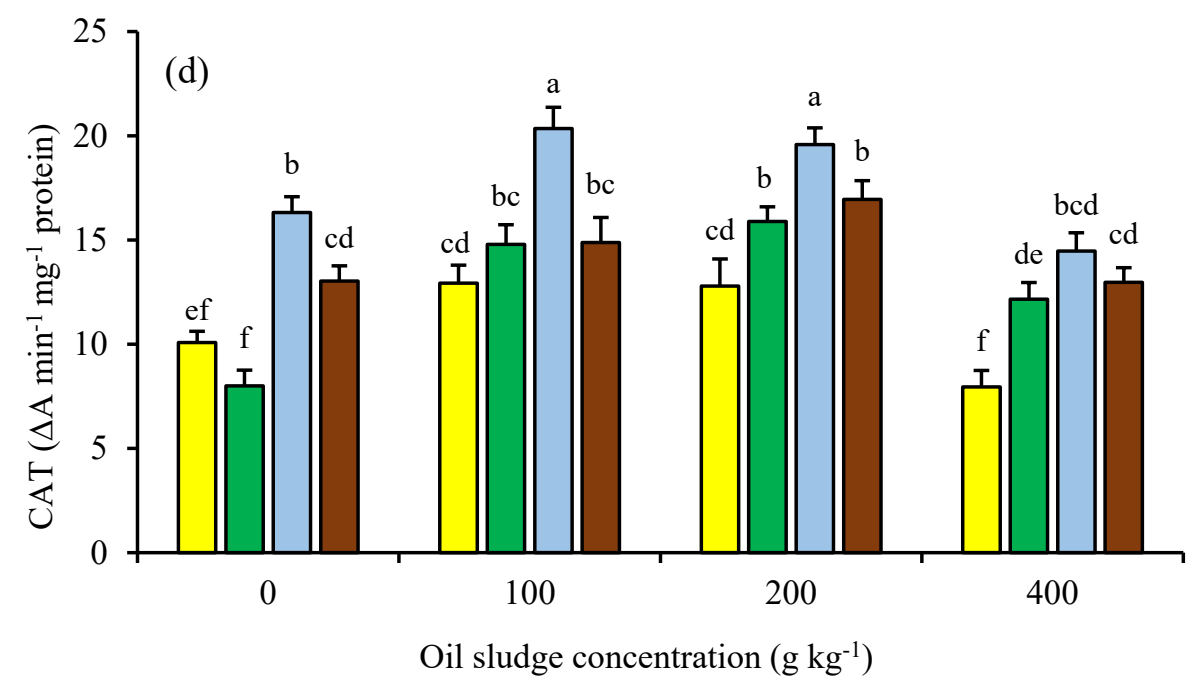

Fig. 2 Oxidative stress $\left(\mathrm{H}_{2} \mathrm{O}_{2}\right)$ and activity of antioxidant defense enzymes in leaves of four species of forest tree seedlings in response to a 240-day oil sludge contamination treatment $\left(0,100,200,400 \mathrm{~g} \mathrm{~kg}^{-1} \mathrm{soil}\right.$. Different lower-case letters indicate statistically significant differences based on Tukey's Honest Significant Difference (HSD) post-hoc test $(\alpha=0.05)$. Means $+\mathrm{SE}, n=3$. POD $=$ peroxidase, APX $=$ ascorbate peroxidase, $\mathrm{CAT}=$ catalase

\section{Discussion}

In the present study, we investigated the effects of soil contamination by oil sludge on the activity of key soil enzymes in the presence and absence of seedlings of four tree species frequently used in plantation projects in the Middle Eastern region in order to guide future afforestation and reforestation activities in oil-contaminated areas. In addition, we also explored changes in $\mathrm{H}_{2} \mathrm{O}_{2}$ content (as a proxy for oxidative stress) and the antioxidant defense system in the leaves of the four tree species in response to oil-induced oxidative stress. The same individuals used here were also used in a complementary study on the effects of oil-sludge contamination on seedling morphology and physiology, where seed germination, seedling survival and growth data were recorded as well, indicating that oil contamination dramatically affects tree growth (see Norouzi Haroni et al., 2019).

\subsection{Soil enzyme activity in response to oil sludge contamination in planted and unplanted soil}

In nearly all instances, we observed a tree-related stimulation of enzymatic activity in oil-contaminated soil relative to the plant-free control, regardless of enzyme type. As anticipated, the magnitude of this stimulatory effect varied significantly in a species-specific manner and also across contamination levels, which was supported by a significant two-way interaction between tree species and oil contamination treatment in the statistical models (Table 3).

Soil dehydrogenase is exclusively produced by living microbial cells and therefore serves as a reliable marker for microbial activity and changes in overall soil metabolism (Jeelani et al. 2018). The rather consistent seedling-driven stimulation of dehydrogenase in oil-contaminated soil suggests greater rhizodeposition or changes in exudate composition promoting microbial activity in comparison with uncontaminated control soil. This result is in line with the findings of Xie et al. (2018) indicating that 
oil contamination may cause compositional changes in root exudates and thereby alter the soil microbial community and activity.

In the unplanted soil, the lack of labile soil carbon inputs and other stimulants from rhizodeposition must have limited microbial growth, which, together with the toxic effects of the oil sludge, was probably the main cause for the lower levels of dehydrogenase activity in seedling-free pots in our study (see also Movafagh et al. 2015). Nonetheless, dehydrogenase activity also rose significantly in unplanted soil in response to low and medium oil sludge contamination (Fig. 1 a) implying increased activity of heterotrophic bacteria decomposing oil compounds and using the intermediates or breakdown products as a source of energy and/or carbon. In line with this notion, Hernández-Ortega et al. (2012) demonstrated that oil sludge may add energy sources such as carbon, nitrogen and sulfur to soils which might promote both mircobial enzyme production and enzyme activity.

Urease is one of the most important amidohydrolases and plays a crucial role in the nitrogen metabolism of soils (Acosta-Martinez \&Tabatabai 2000). The trend for urease activity strongly resembled the dehydrogenase pattern but here we observed no increase in activity in unplanted soil with increasing oil contamination indicating that urease-producing soil microorganisms were not able to use oil compounds as a source of energy or carbon (Fig. 1 b). Unplanted soils always showed the lowest activities of urease and dehydrogenase compared to soil planted with tree seedlings highlighting the stimulatory effect of roots on microbial enzyme production and secretion (Yang et al., 2012). The large enzymatic stimulation of dehydrogenase and urease caused by $R$. pseudoacacia at the low and intermediate and by $F$. rotundifolia at the highest oil contamination level suggests that these species either release more root exudates or that their exudates undergo more beneficial changes in response to oil contamination at these levels compared to A. altissima and M. azedarach. The great magnitude of the stimulatory effect of $R$. pseudoacacia may be largely due to increases in dissolved organic nitrogen originating from the symbiotic nitrogen fixation. Between 1 and $2 \%$ of the nitrogen fixed by R. pseudoacacia has been reported to find its way into the soil with root exudates (Please find and add the following citation: Uselman et al. 1999).

Oil sludge contains numerous heavy metals $(\mathrm{Ca}, \mathrm{Cd}, \mathrm{Cu}, \mathrm{Pb})$ which may cause denaturation of enzymes (Vig et al. 2003) and this was probably the reason for the decreased activity of dehydrogenase and urease in the rhizosphere of $R$. pseudoacacia seedlings growing in heavy metal-contaminated soil in a study by Huang et al. (2016). The heavy metal concentration in our oil-contaminated soils was lower compared to the experiment of Huang et al. (2016), but we have also recorded a decrease in dehydrogenase and urease activity with increasing oil-contamination in soil planted with $R$. pseudoacacia. However, if this decline in enzyme activity was mainly driven by heavy metal toxicity, then we should have seen a similar pattern of decline in soil under the remaining species too, unless we presume a protective rhizosphere effect that varies with tree species depending on the level of contamination. In the rhizosphere, the heavy metal-induced denaturation of soil enzymes is mitigated due to the strong chelating properties of organic acids in root exudates and therefore the extent of 
denaturation processes may be controlled to a degree by the amount of root exudates or their composition (Mehrdad, please find and a couple of references in support of this and insert them here. I think the following book would work (mentioned in Rosselli, Keller \& Boschi (2003)): Blaylock M J and Huang J W 2000 Phytoextraction of metals. In Phytoremediation of Toxic Metals: Using Plants to Clean up the Environment. Eds. Raskin I and Ensley B D. pp. 314. John Wiley and Sons Inc., New York.). This would imply a decrease in rhizodeposition or unfavourable compositional changes in root exudates of $R$. pseudoacacia with increasing oil-contamination, whereas the opposite should then be true for the three remaining tree species as they all showed a significant increase in their stimulatory effect on enzyme activity from the 200 to the $400 \mathrm{~g} \mathrm{~kg}^{-1}$ contamination level. However, our foliar $\mathrm{H}_{2} \mathrm{O}_{2}$ data suggest oxidative damage as the most plausible explanation for the pattern associated with $R$. pseudoacacia. The significant decrease in the magnitude of the stimulation of dehydrogenase and urease activity with increasing oil contamination in $R$. pseudoacacia-planted pots was mirrored by a corresponding increase in foliar $\mathrm{H}_{2} \mathrm{O}_{2}$ content. Thus, we speculate that oxidative damage in leaves could have disrupted leaf carbohydrate metabolism resulting in curtailed resource allocation below ground which translates into reduced rhizodeposition and microbial stimulation.

The activity of phosphatase enzymes in soil is the major driver of organic phosphorus supply under mineral phosphorus deficiency (Helal \& Dressler 1989). While acid phosphatase is formed by plant roots and microorganisms, alkaline phosphatase is predominantly produced by microorganisms (Marschner 2012). The significant increase in acid phosphatase activity in unpolluted soil planted with tree seedlings relative to the unplanted control highlights the plant contribution to the soil acid phosphatase pool through excretion and the rhizosphere effect. Acid phosphatase activity showed only minor changes in unplanted soil in response to rising oil pollution levels. However, in planted soil acid phosphatase activity generally increased with increasing oil sludge concentration but at the highest concentration enzymatic activity returned to levels similar to or slightly lower than those observed in the control (Fig. 1c). These findings suggest that exposure to oil sludge contamination can boost acid phosphatase production and secretion in tree roots but seems to have little or no effect on microbial acid phosphatase. Our data further indicate that this oil-driven stimulatory effect is vanishing at medium (see $F$. rotundifolia) to high oil contamination levels.

Alkaline phosphatase activity is also controlled by organic phosphorus availability and the $\mathrm{pH}$ in the soil and therefore changes in those variables associated with the presence of oil sludge or its decomposition processes may certainly have an effect on the activity of this enzyme (Lai et al. 2011). In our study, the activity of alkaline phosphatase in unplanted control soil did not change significantly with increasing oil contamination level suggesting no oil-related effects on the functioning of this enzyme or its microbial synthesis in the range of the oil sludge concentrations tested (Fig. $1 \mathrm{~d}$ ). On the other hand, tree seedling presence significantly stimulated alkaline phosphatase activity relative to the unplanted control at each contamination level and this was most likely due to root secretions which have been shown to directly affect phosphatase activity in the rhizosphere (Thomson et al. 1986). Our 
findings imply that seedling rhizodeposition in uncontaminated soil increased the activity of alkaline phosphatase, except for soil planted with A. altissima where alkaline phosphatase activity remained unchanged relative to the unplanted control suggesting that a key stimulating compound (or several) was lacking in its root exudates. As judged by the strong alkaline phosphatase stimulation in the uncontaminated control soil and in the $100 \mathrm{~g} \mathrm{~kg}^{-1}$ contamination treatment, the composition of root exudates of $F$. angustifolia must have been very beneficial to soil microbes. However, the marked decrease by more than $50 \%$ in the stronger contamination treatments implies changes in exudate composition rather than in volume since reductions in the amount of root exudates would have been reflected in a declining stimulatory effect on dehydrogenase and urease. $R$. pseudoacacia consistently stimulated alkaline phosphatase activity and this effect was significantly higher compared to the remaining species at the two highest contamination levels. A strong stimulatory effect of $R$. pseudoacacia on alkaline phosphatase was also found in a study from the Loess Plateau in western China by Qiu et al. (2010) who linked the stimulation to the increase in labile organic carbon and total nitrogen in the rhizosphere of $R$. pseudoacacia. (And here is the reference: Qui L et al. (2010) Effects of black locust (Robinia pseudoacacia) on soil properties in the loessial gully region of the Loess Plateau, China.).

\subsection{Impact of oil sludge contamination on foliar $\mathrm{H}_{2} \mathrm{O}_{2}$ content and antioxidant enzymes}

When oil sludge is introduced to a vegetated site, it commonly causes oxidative stress in plants due to the deficiency of oxygen molecules and generation of reactive oxygen species (ROS) (Liu et al. 2009). Oil products and hydrocarbons can induce the generation of ROS such as the superoxide anion, hydrogen peroxide and hydroxyl ions in plant cells (Habiba et al. 2015, Tauqeer et al. 2016, Zhang et al. 2007). This is corroborated by our results, which showed that $\mathrm{H}_{2} \mathrm{O}_{2}$ levels in tree seedlings increased with increasing oil sludge contamination. This is most likely due to the production of free radicals through Weiss-Haber reactions, which can ultimately raise the level of toxicity (Bouazizi et al. 2007). In our study, we have used $\mathrm{H}_{2} \mathrm{O}_{2}$ as a proxy for oxidative stress and observed increasing levels thereof in tree seedlings with increasing oil sludge contamination in a species-specific manner. Hydrogen peroxide can be eliminated by antioxidant enzymes such as POD, APX, and CAT (Sharma et al. 2017a, Sharma et al. 2017b, Sharma et al. 2012), therefore we also studied the activity of these enzymes in seedling foliage in response to oil contamination. The foliar $\mathrm{H}_{2} \mathrm{O}_{2}$ content as well as the activity of three major antioxidant enzymes varied significantly among species depending on oil contamination level, which was statistically supported by a significant two-way interaction. Interestingly, $R$. pseudoacacia seems to be able to ward off oxidative damage at low oil contamination as evidenced by the lack of increase in foliar $\mathrm{H}_{2} \mathrm{O}_{2}$ at the $100 \mathrm{~g} \mathrm{~kg}^{-1}$ oil sludge treatment. However, the relatively strong accumulation of $\mathrm{H}_{2} \mathrm{O}_{2}$ in the most severe oil contamination treatment implies that the antioxidant pool responsible for the initial protection appears to become rapidly exhausted. The lack of a corresponding increase in activity of any of the major antioxidant enzyme classes in $R$. pseudoacacia foliage at $100 \mathrm{~g} \mathrm{~kg}^{-1}$ oil sludge addition suggests that the antioxidant protection may 
have been conferred by non-enzymatic antioxidants such as flavonoids, non-flavonoid phenolics, tocopherols, carotenoids, ascorbic acid and other compounds, which have been reported to be present in large numbers in $R$. pseudoacacia (Please add the following reference here: Tyśkiewicz et al. (2019): Characterization of bioactive compounds in the biomass of black locust, poplar and willow. TREES, 33, 1235-1263).

In line with our results, Yang et al. (2015) reported that the $\mathrm{H}_{2} \mathrm{O}_{2}$ level in the leaves of $R$. pseudoacacia increased linearly with increasing lead $(\mathrm{Pb})$ concentration in the soil. Our findings further indicate that the antioxidant defense of A. altissima relies heavily on APX and to a somewhat lesser extent on CAT, whereas POD only plays a major role at low oil contamination levels. APX has been shown to be more efficient in the elimination of ROS in comparison with other peroxidase and catalase enzymes (Mohsenzadeh 2018) and thus the strong reliance on such a strong ROS quencher indicates higher oxidative stress in A. altissima than in the other species. The antioxidant defense system of $F$. rotundifolia depends on all three enzymes at low and intermediate levels of oil contamination but under more severe contamination CAT and possibly other compounds not investigated here play a more dominant role in combating oxidative stress. Remarkably, all enzyme activities in M. azedarach foliage dropped back down to control levels at the highest oil sludge exposure but its foliar $\mathrm{H}_{2} \mathrm{O}_{2}$ content did not significantly increase from the $200 \mathrm{~g} \mathrm{~kg}^{-1}$ to the most severe oil contamination implying a shift towards other enzymatic or non-enzymatic antioxidants. The reduced activity of POD in $F$. rotundifolia, A. altissima and $M$. azedarach at the 200 and $400 \mathrm{~g} \mathrm{~kg}^{-1}$ oil sludge additions might have resulted from the accumulation of toxic compounds in the plant cell inhibiting enzyme functioning and aside from this, increasing levels of $\mathrm{H}_{2} \mathrm{O}_{2}$ and other ROS may have caused molecular damage that lessened the activity of POD (Patidar et al. 2017). Previous research has shown that peak POD activity occurs at low levels of abiotic stress (Das \& Roychoudhury 2014b, Kord et al. 2010, Sharma et al. 2016), which is in line with our findings. Moreover, POD can be regarded as an indicator of heavy metal stress in the cytosol, cell wall and vacuoles, and its enzymatic activity depends on the production of $\mathrm{H}_{2} \mathrm{O}_{2}$ and phenolic compounds (Ahmadvand et al. 2014). Because $R$. pseudoacacia was the only species whose POD activity remained significantly elevated at the highest oil contamination level in comparison with the control, it is plausible to assume that this species experienced more heavy metalrelated stress than the others. The declining enzyme activity observed in most cases at $400 \mathrm{~g} \mathrm{~kg}^{-1}$ contamination level can probably be attributed to the accumulation of ROS and the progressing exhaustion of the antioxidant defense system, which may even be accelerated through the activation of peroxisomal proteases under extreme stress conditions (Tang et al. 2010, Das \& Roychoudhury 2014a, Sharma et al. 2018).

Antioxidant enzymes are commonly regarded as oxidative stress markers and therefore the strong activity of these enzymes (APX and CAT in particular) in A. altissima seedlings exposed to oil sludge exposure suggests higher levels of oxidative stress compared to the remaining species. The antioxidant defense system of $A$. altissima allowed $\mathrm{H}_{2} \mathrm{O}_{2}$ quenching to the same extent as $F$. rotundifolia and $M$. 
azedarach but involved a higher metabolic cost and we cannot preclude that other, unmeasured ROS species have increased.

\section{Conclusion}

Our findings underline the importance of the rhizosphere effect for enzyme-driven reactions central to soil restoration. The observed species-specific stimulation of soil enzyme activity implies potential for enhancing phytoremediation efficiency through carefully engineered plant species assemblages. Using nitrogen-fixing woody phytoremediator species such as $R$. pseudoacacia may provide an extra boost for soil microbial activity, especially in nitrogen-poor soils. Our study indicates that $R$. pseudoacacia is particularly well-suited for phytoremediation projects dealing with low to intermediate oil pollution levels and also at highly oil-polluted sites with phosphorous-poor soil where a strong stimulatory effect on alkaline phosphatase is desirable to increase phosphorous availability. Greater seedling survival and growth under severe oil-contamination together with reasonably strong enzymatic stimulation make $M$. azedarach and $F$. rotundifolia (strong stimulation of dehydrogenase and urease) ideal phytoremediator species at highly oil-polluted sites. Moreover, our study identified oxidative stress tolerance as a functional trait to be considered in candidate tree species for phytoremediation of oil-contaminated soils. Among the species tested here, A. altissima seems to experience the highest level of oil-induced oxidative stress, which may translate into increased oxidative damage and decreased seedling growth and we therefore rank its phytoremediation potential lowest.

Conflict of Interest: The authors declare that they have no conflict of interest.

\section{References}

Acosta-Martinez V, Tabatabai M (2000): Enzyme activities in a limed agricultural soil. Biology and Fertility of Soils 31, 85-91

Aebi H (1974): Catalase, Methods of enzymatic analysis. Elsevier, pp. 673-684

Agnello AC, Bagard M, Van Hullebusch ED, Esposito G, Huguenot D (2016): Comparative bioremediation of heavy metals and petroleum hydrocarbons co-contaminated soil by natural attenuation, phytoremediation, bioaugmentation and bioaugmentation-assisted phytoremediation. Science of the total environment 563, 693-703

Ahmadvand H, Amiri H, Dehghani Elmi Z, Bagheri S (2014): Chemical composition and antioxidant properties of Ferula-assa-foetida leaves essential oil. Iranian Journal of Pharmacology and Therapeutics 12, 52-0

Anandham R, Indiragandhi P, Madhaiyan M, Saravanan V, Sa T (2007): Isolation and characterization of thiosulfate oxidizing bacteria from rhizosphere soils of crop plants of Korea. Environment Science 5, 114

Azevedo H, Glória Pinto CG, Santos C (2005): Cadmium effects in sunflower: membrane permeability and changes in catalase and peroxidase activity in leaves and calluses. Journal of plant nutrition 28, 22332241

Banks M, Schwab P, Liu B, Kulakow P, Smith J, Kim R (2003): The effect of plants on the degradation and toxicity of petroleum contaminants in soil: a field assessment, Phytoremediation. Springer, pp. 75-96

Beškoski VP, Gojgić-Cvijović G, Milić J, Ilić M, Miletić S, Šolević T, Vrvić MM (2011): Ex situ bioremediation of a soil contaminated by mazut (heavy residual fuel oil)-A field experiment. Chemosphere 83, 34-40 
Bouazizi H, Jouili H, El Ferjani E (2007): Effects of Copper Excess on Growth, H, O, Production and Peroxidase Activities in Maize Seedlings (Zea mays L.). Pakistan Journal of Biological Sciences 10, 751-756

Bouyoucos GJJAj (1962): Hydrometer method improved for making particle size analyses of soils 1. 54, 464465

Brakorenko NN, Korotchenko TV (2016): Impact of petroleum products on soil composition and physicalchemical properties, IOP Conference Series: Earth and Environmental Science. IOP Publishing, pp. 012028

Brandt R, Merkl N, Schultze-Kraft R, Infante C, Broll G (2006): Potential of vetiver (Vetiveria zizanioides (L.) Nash) for phytoremediation of petroleum hydrocarbon-contaminated soils in Venezuela. International journal of phytoremediation 8, 273-284

Burns RG (1982): Enzyme activity in soil: location and a possible role in microbial ecology. Soil Biology Biochemistry 14, 423-427

Burt R (2004): Soil survey laboratory methods manual. Casida Jr L, Klein D, Santoro TJSs (1964): Soil dehydrogenase activity. 98, 371-376

Das K, Roychoudhury A (2014a): Reactive oxygen species (ROS) and response of antioxidants as ROSscavengers during environmental stress in plants. Frontiers in Environmental Science 2, 53

Das K, Roychoudhury AJFiES (2014b): Reactive oxygen species (ROS) and response of antioxidants as ROSscavengers during environmental stress in plants. 2, 53

Das SK, Varma A (2010): Role of enzymes in maintaining soil health, Soil enzymology. Springer, pp. 25-42

Dick RP (1992): A review: long-term effects of agricultural systems on soil biochemical and microbial parameters. Agriculture, ecosystems \& environment 40, 25-36

Dick, R P, Kandeler, E (2005). Enzymes in soils. Encyclopedia of Soils in the Environment. 448-456.

Dindar E, Şağban FOT, Başkaya HS (2015): Variations of soil enzyme activities in petroleum-hydrocarbon contaminated soil. International Biodeterioration \& Biodegradation 105, 268-275

Gianfreda L, Rao MAJCRiES, Technology (2008): Interactions between xenobiotics and microbial and enzymatic soil activity. 38, 269-310

Grossman R, Reinsch TJMosaPpm (2002): 2.1 Bulk density and linear extensibility. 201-228

Habiba U, Ali S, Farid M, Shakoor MB, Rizwan M, Ibrahim M, Abbasi GH, Hayat T, Ali B (2015): EDTA enhanced plant growth, antioxidant defense system, and phytoextraction of copper by Brassica napus L. Environmental Science and Pollution Research 22, 1534-1544

Helal HM, Dressler A (1989): Mobilization and turnover of soil phosphorus in the rhizosphere. Zeitschrift für Pflanzenernährung und Bodenkunde 152, 175-180

Hernández-Ortega HA, Alarcón A, Ferrera-Cerrato R, Zavaleta-Mancera HA, López-Delgado HA, MendozaLópez MR (2012): Arbuscular mycorrhizal fungi on growth, nutrient status, and total antioxidant activity of Melilotus albus during phytoremediation of a diesel-contaminated substrate. Journal of environmental management 95, S319-S324

Hsu S-Y, Kao CH (2003): Differential effect of sorbitol and polyethylene glycol on antioxidant enzymes in rice leaves. Plant Growth Regulation 39, 83-90

Huang S, Jia X, Zhao Y, Chang Y, Bai BJAse (2016): Response of Robinia pseudoacacia L. rhizosphere microenvironment to $\mathrm{Cd}$ and $\mathrm{Pb}$ contamination and elevated temperature. 108, 269-277

Institute S (1999): SAS Procedures Guide: Version 8, 1. Sas Inst

IRIMO (2014): IR of Iran Meteorological Org (IRIMO), 2014. The meteorology of the khoram abad

Township http://www.irimo.ir/english/. Accessed April 2014.

Jeelani N, Yang W, Qiao Y, Li J, An S, Leng X (2018): Individual and combined effects of cadmium and polycyclic aromatic hydrocarbons on the phytoremediation potential of Xanthium sibiricum in cocontaminated soil. International journal of phytoremediation 20, 773-779

Jia X, Zhang C, Zhao Y, Liu T, He YJJohm (2018): Three years of exposure to lead and elevated CO2 affects lead accumulation and leaf defenses in Robinia pseudoacacia L. seedlings. 349, 215-223

Kord B, Mataji A, Babaie SJJJoES, Technology (2010): Pine (Pinus Eldarica Medw.) needles as indicator for heavy metals pollution. 7, 79-84

Kourtev PS, Ehrenfeld JG, Häggblom M (2002): Exotic plant species alter the microbial community structure and function in the soil. Ecology 83, 3152-3166

Kriksunov E (2011): Marine oil spills: the causes, environmental impact, prevention methods, response operations. Water Resources 38, 684-685 
Lemanowicz J (2018): Dynamics of phosphorus content and the activity of phosphatase in forest soil in the sustained nitrogen compounds emissions zone. Environmental Science and Pollution Research volume. 25, 33773-33782

Lai J, Yu Z, Song X, Cao X, Han X (2011): Responses of the growth and biochemical composition of Prorocentrum donghaiense to different nitrogen and phosphorus concentrations. Journal of Experimental Marine Biology and Ecology 405, 6-17

Liao C, Xu W, Lu G, Liang X, Guo C, Yang C, Dang Z (2015): Accumulation of hydrocarbons by maize (Zea mays L.) in remediation of soils contaminated with crude oil. International journal of phytoremediation 17, 693-700

Liu F, Ying G-G, Tao R, Zhao J-L, Yang J-F, Zhao L-F (2009): Effects of six selected antibiotics on plant growth and soil microbial and enzymatic activities. Environmental pollution 157, 1636-1642

Ma S-C, Zhang H-B, Ma S-T, Wang R, Wang G-X, Shao Y, Li C-XJE, safety e (2015): Effects of mine wastewater irrigation on activities of soil enzymes and physiological properties, heavy metal uptake and grain yield in winter wheat. 113, 483-490

Maila MP, Cloete TE (2005): The use of biological activities to monitor the removal of fuel contaminantsperspective for monitoring hydrocarbon contamination: a review. International Biodeterioration \& Biodegradation 55, 1-8

Margalef O, Sardans J, Fernández-Martínez M, Molowny-Horas R, Janssens I, Ciais P, Goll D, Richter A, Obersteiner M, Asensio D (2017): Global patterns of phosphatase activity in natural soils. Scientific reports 7, 1337

Marschner P (2012): Rhizosphere biology, Marschner's Mineral Nutrition of Higher Plants (Third Edition). Elsevier, pp. 369-388

Martinez-Salgado M, Gutiérrez-Romero V, Jannsens M, Ortega-Blu R (2010): Biological soil quality indicators: a review. Current Research, Technology and Education Topics in Applied Microbiology and Microbial Biotechnology 1, 319-328

Mithöfer A, Schulze B, Boland W (2004): Biotic and heavy metal stress response in plants: evidence for common signals. FEBS letters 566, 1-5

Mohsenzadeh F (2018): Removing of Benzo [a] pyrene using the Isolated Fungi from Petroleum-polluted Soils. Toxicology and Environmental Health Sciences 10, 123-131

Movafagh S, Crook S, Vo K (2015): Regulation of hypoxia-inducible factor-1a by reactive oxygen species: new developments in an old debate. Journal of cellular biochemistry 116, 696-703

Mueller JG, Middaugh DP, Lantz SE, Chapman P (1991): Biodegradation of creosote and pentachlorophenol in contaminated groundwater: chemical and biological assessment. Applied and Environmental Microbiology 57, 1277-1285

Nakano Y, Asada KJP, physiology c (1981): Hydrogen peroxide is scavenged by ascorbate-specific peroxidase in spinach chloroplasts. 22, 867-880

Nanekar S, Dhote M, Kashyap S, Singh S, Juwarkar AA (2015): Microbe assisted phytoremediation of oil sludge and role of amendments: a mesocosm study. International Journal of Environmental Science and Technology 12, 193-202

Nannipieri P, Grego S, Ceccanti B, Bollag J, Stotzky GJSb (1990): Ecological significance of the biological activity in soil, pp. 1990. 293-355.

Osse M, Hamel J-F, Mercier A (2018): Markers of oil exposure in cold-water benthic environments: Insights and challenges from a study with echinoderms. Ecotoxicology and environmental safety 156, 56-66

Panchenko L, Muratova A, Turkovskaya O (2017): Comparison of the phytoremediation potentials of Medicago falcata L. And Medicago sativa L. in aged oil-sludge-contaminated soil. Environmental Science and Pollution Research 24, 3117-3130

Patidar K, Chouhan A, Thakur LS (2017): Removal of Heavy Metals from Water and Waste Water by Electrocoagulation Process-A Review. Int. Res. J. Eng. Technol.(IRJET) 4, 16-25

Raiesi F, Beheshti A (2015): Microbiological indicators of soil quality and degradation following conversion of native forests to continuous croplands. Ecological indicators 50, 173-185

Roy AS, Baruah R, Borah M, Singh AK, Boruah HPD, Saikia N, Deka M, Dutta N, Bora TC (2014): Bioremediation potential of native hydrocarbon degrading bacterial strains in crude oil contaminated soil under microcosm study. International Biodeterioration \& Biodegradation 94, 79-89 
Sajna KV, Sukumaran RK, Gottumukkala LD, Pandey A (2015): Crude oil biodegradation aided by biosurfactants from Pseudozyma sp. NII 08165 or its culture broth. Bioresource technology 191, 133139

Sharma A, Kumar V, Thukral AK, Bhardwaj RJIJoPP (2016): Epibrassinolide-imidacloprid interaction enhances non-enzymatic antioxidants in Brassica juncea L. Environmental Science and Pollution Research 21, 70-75

Sharma A, Kumar V, Kanwar M, Thukral A, Bhardwaj RJRJoPP (2017a): Ameliorating imidacloprid induced oxidative stress by 24-epibrassinolide in Brassica juncea L. Environmental Science and Pollution Research 64, 509-517

Sharma A, Thakur S, Kumar V, Kesavan AK, Thukral AK, Bhardwaj RJBpb (2017b): 24-epibrassinolide stimulates imidacloprid detoxification by modulating the gene expression of Brassica juncea L. BMC Plant Biology 17, 56

Sharma A, Kumar V, Yuan H, Kanwar MK, Bhardwaj R, Thukral AK, Zheng BJFiPS (2018): Jasmonic acid seed treatment stimulates insecticide detoxification in Brassica juncea L. Frontiers in Plant Science 9, $1-17$

Sharma P, Jha AB, Dubey RS, Pessarakli M (2012): Reactive oxygen species, oxidative damage, and antioxidative defense mechanism in plants under stressful conditions. Journal of botany 2012

Tabatabai M, Bremner JJSb, biochemistry (1969): Use of p-nitrophenyl phosphate for assay of soil phosphatase activity. 1, 301-307

Tabatabai M, Bremner JJSB, biochemistry (1972): Assay of urease activity in soils. 4, 479-487

Tang J, Wang R, Niu X, Zhou Q (2010): Enhancement of soil petroleum remediation by using a combination of ryegrass (Lolium perenne) and different microorganisms. Soil and Tillage Research 110, 87-93

Tauqeer HM, Ali S, Rizwan M, Ali Q, Saeed R, Iftikhar U, Ahmad R, Farid M, Abbasi GH (2016): Phytoremediation of heavy metals by Alternanthera bettzickiana: growth and physiological response. Ecotoxicology and environmental safety 126, 138-146

Thomson B, Robson A, Abbott L (1986): Effects of phosphorus on the formation of mycorrhizas by Gigaspora calospora and Glomus fasciculatum in relation to root carbohydrates. New phytologist 103, 751-765

Tripathy S, Bhattacharyya P, Mohapatra R, Som A, Chowdhury DJEe (2014): Influence of different fractions of heavy metals on microbial ecophysiological indicators and enzyme activities in century old municipal solid waste amended soil. $70,25-34$

Varjani SJ, Upasani VN (2017): A new look on factors affecting microbial degradation of petroleum hydrocarbon pollutants. International Biodeterioration \& Biodegradation 120, 71-83

Velikova V, Yordanov I, Edreva AJPs (2000): Oxidative stress and some antioxidant systems in acid rain-treated bean plants: protective role of exogenous polyamines. 151, 59-66

Vig K, Megharaj M, Sethunathan N, Naidu RJAiER (2003): Bioavailability and toxicity of cadmium to microorganisms and their activities in soil: a review. 8, 121-135

Wang J, Zhang Z, Su Y, He W, He F, Song H (2008): Phytoremediation of petroleum polluted soil. Petroleum Science 5, 167-171

Wang W, Freemark K (1995): The use of plants for environmental monitoring and assessment. Ecotoxicology and environmental safety 30, 289-301

Wyszkowska J, Wyszkowski M (2010): Activity of soil dehydrogenases, urease, and acid and alkaline phosphatases in soil polluted with petroleum. Journal of Toxicology and Environmental Health, Part A $73,1202-1210$

Wyszkowska J, Wyszkowski MJJoT, Environmental Health PA (2010): Activity of soil dehydrogenases, urease, and acid and alkaline phosphatases in soil polluted with petroleum. 73, 1202-1210

Xiao N, Liu R, Jin C, Dai Y (2015): Efficiency of five ornamental plant species in the phytoremediation of polycyclic aromatic hydrocarbon (PAH)-contaminated soil. Ecological Engineering 75, 384-391

Xie W, Li R, Li X, Liu P, Yang H, Wu T, Zhang Y (2018): Different responses to soil petroleum contamination in monocultured and mixed plant systems. Ecotoxicology and environmental safety 161, 763-768

Xun W, Huang T, Zhao J, Ran W, Wang B, Shen Q, Zhang R (2015): Environmental conditions rather than microbial inoculum composition determine the bacterial composition, microbial biomass and enzymatic activity of reconstructed soil microbial communities. Soil Biology and Biochemistry 90, 10-18

Yang Y, Han X, Liang Y, Ghosh A, Chen J, Tang MJPO (2015): The combined effects of arbuscular mycorrhizal fungi (AMF) and lead $(\mathrm{Pb})$ stress on $\mathrm{Pb}$ accumulation, plant growth parameters, photosynthesis, and antioxidant enzymes in Robinia pseudoacacia L. 10, e0145726 
Zamani J, Hajabbasi MA, Alaie E, Sepehri M, Leuchtmann A, Schulin R (2016): The effect of Piriformospora indica on the root development of maize (Zea mays L.) and remediation of petroleum contaminated soil. International journal of phytoremediation 18, 278-287.

Zarafshar Me, Bazot S, Matinizadeh M, Bordbar S K, Rousta M J, Kooch Y, Enayati K, Abbasi A, Negahdarsaber M (2020): Do tree plantations or cultivated fields have the same ability to maintain soil quality as natural forests?. Applied soil ecology. 151, 103536.

Zhang F-Q, Wang Y-S, Lou Z-P, Dong J-D (2007): Effect of heavy metal stress on antioxidative enzymes and lipid peroxidation in leaves and roots of two mangrove plant seedlings (Kandelia candel and Bruguiera gymnorrhiza). Chemosphere 67, 44-50

Zhang Z, Qu W (1990): Experiment guide of plant physiology. High Education Press Beijin, China china. Chinese 